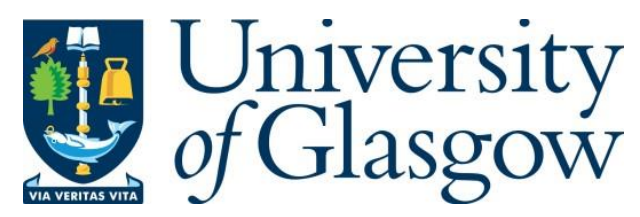

Lorimer, H. (2019) Dear departed: writing the lifeworlds of place. Transactions of the Institute of British Geographers, 44(2), pp. 331-345.

This is the peer reviewed version of the following article: Lorimer, H. (2019) Dear departed: writing the lifeworlds of place. Transactions of the Institute of British Geographers, 44(2), pp. 331-345, which has been published in final form at http://dx.doi.org/10.1111/tran.12278

This article may be used for non-commercial purposes in accordance with Wiley Terms and Conditions for Self-Archiving.

http://eprints.gla.ac.uk/173565/

Deposited on: 7 January 2019

Enlighten - Research publications by members of the University of Glasgow http://eprints.gla.ac.uk 


\title{
DEAR DEPARTED: WRITING THE LIFEWORLDS OF PLACE
}

\begin{abstract}
This essay is concerned with the lifeworlds of place, and the significant part that the storied word might play in them. It considers the modern disciplinary history of place study, and styles of creative geographical writing presently being employed to configure place as a lived phenomenon, with a past, present and future. Across the piece, an experiment in place-portraiture unfolds, according to a series of episodes penned in non-fiction prose. The muse for these meditations is an arresting site reserved for burying the remains of loved ones: a seaside pet cemetery. Deep diving into the cemetery's place lore, and the life of its custodian, 'The Keeper', the essay explores the loss, love and longing felt for domestic companion animals by grieving humans, the better to understand a nexus of geographies; variously, of memory, emotion, intimacy, responsibility and creativity. The essay closes by reflecting on how a sustained fusion of site, subject and style can give voice to a language of radical parochialism and, simultaneously, reset the wider representational project by which geographers engage proprietary feelings about place, its presumed fate and possible prospects. In its avoidance of a more conventional academic mode, and adoption of descriptive geographical narratives, the article offers an alternate literary model by which pressing environmental challenges might yet be affectively articulated and addressed.
\end{abstract}

Keywords: place, writing, death, memory, emotion, coastlines 


\section{Pet project}

'All great civilizations are built on parochialism...Parochialism is a universal and deals with fundamentals'

(Kavanagh, 1952: 237)

Like many a pet project, I've been at this one for what already feels like far too long. Trying to find a language that really values the life of the place. Words to describe how the stonework, found in muted shades around the former fishing port, is sent scintillating when cast in pale evening light. How folk talk of belonging here, in soft tones, seldom meeting the eye, conscious of some want of tact. Of spells when the sea air drifts inshore, moving up country, estranging the farmland that fringes the Moray Firth.

For the getaway weekender who finds the seaside restorative, all the traditional resort attractions await discovery. Candy-striped cafés compete for passing trade with the ice-cream parlor. The antiques mart and curiosity shops for mooching about in if the weather turns. Below the main street, there's the huddle of squat fishermen's cottages, then the concave cement defence of the seawall, and finally the slow curve of the bay, with views to a northerly horizon and the faraway peaks of Caithness. Nature seekers who head west are drawn to crumbling sea stacks and the drama of natural arches. Eastward, the cliffsides grow grassier. At the water's edge there are flaggy, fossil-bearing beds of red sandstone, and the timeless appeal of tidal rock pools. 
If the harbour is the town's historic haven, its emotional centre of gravity is a less likely landmark: the shorefront pet cemetery. There's something invitingly wayward and talismanic about a site where the dead are put to work, cohabiting with the living. For residents and visitors, animal lovers and accidental passersby, the pearly gates to pet heaven are encountered after the last house has been passed, just where the tarmac surface of the port road downgrades to a gravelly coastal track. The very point, as it turns out, where the Google Maps vehicle snapped a final $360^{\circ}$ panorama before executing a tight U-turn. What the Street View surveyors partially captured on camera, for anyone anywhere to see, is a picturesque resting place, devoted to domesticated companion animals. ${ }^{1}$ All creatures great and small, the recently deceased, and long since departed. Top to bottom, side to side, the cemetery consumes less than an acre of waste ground. And at the same time, it belies its own scale, feeling quite outsized in metaphysical proportion: a lesser landmass, a micro-cosmos, and an entire region of experience.

Over the past few years, I have penned a love letter to this place's particularity. Treading then retreading the postage-stamp of a plot. Taking my own snapshots to see what slips in and out of focus. Finding fresh routes through its narrative riches and sharp specifics. Insofar as there is a research method to speak of, mine has been to contemplate this place for as long as it takes to understand it. A site-based ethnography and oral history: of a fashion. Activities have happened unmethodically. By fits and starts, on fair days and foul, in high summer and out of season, letting the place work on me, as much as me on it. Visit by visit, I've coaxed and extracted, as much a beachcomber as scholar. Unearthing the rhythms of memory and consciousness amidst relics forms and communal life. Growing attuned to the sharp intensities of loss felt in bereavement, the tender intimacies of inter-species 
communion and, what some place frequenters reckon to be, evidence of immortal souls and spiritual transmutation.

This observational essay marks another transition, from pet project into formal place-portrait. To keep the cemetery front-and-centre, it is structured as a series of recounted scenes, each an object lesson informed by tiny concrete details. Each narrative part treats geographies of burial and practices of remembrance as compelling manifestations of what Feigel and Harris (2009: 3) describe as 'the complex imaginative life of the coast'. My intention here is not simply to recount time spent at one scenic stretch of Scotland's coastline, but rather to gather up resources for commentary of wider notice, on the revival of a geographical tradition of 'place-writing', and, the role that language and story play in addressing the existential future of place. As such this essay explores, and at the same time seeks to exhibit, time-honored geographical concerns, namely: a felt-world of relations between people and place, and, the precision necessary to let prose and planet properly correspond. Explaining my direction of travel - from deeply personal enterprise towards greater prospectus - requires fuller consideration of the recent disciplinary history of place studies.

\section{Place studies: predicaments and potentials}

'Place' is regarded a key concept in geography's modern vocabulary, reflecting a more than half century-old humanistic tradition, variously revisited and reinvented (Lowenthal 1961; Buttimer 1976; Relph 1976; Tuan 1977; Cresswell 2004; Hubbard and Kitchin 2011). Questions of how place is made, afforded meaning and keenly contested represent a staple of the undergraduate degree programme. For learning geographers, the skills of place 
interpretation are an accepted benchmark and form of fieldwork inquiry, recently extending into the UK-schools curriculum (AQA 2016). If status in the disciplinary canon is today assured, the means to communicate a 'sense of place' effectively and affectively are less certain. That quandary is encapsulated in the observation, commonly heard, that it is a quality "hard to describe, but I know it when I feel it". Expressed so, genius loci holds the status of a presence of mind. In many respects, that sensing of place becomes an enigmatic formulation only once committed to the written word, as much an ontological predicament as it is ever an analytical achievement.

A sense of place can be derived from a cherished locale, to the point of deep emotional attachment, but it might also be the source of feelings of estrangement and alienation. Mixed feelings for place, and fears about its demise, occur variously: as personal experience, social anxiety, political cause, environmental campaign or material fact, operating in different combination depending on circumstance (Casey 1998; Cresswell 2012). When place is judged to be in peril, concern is commonly figured around a rhetoric of externalized threat and the charged symbolism of endangerment or retrenchment. Worries over social and cultural change can intensify into existential dread about the integrity of place and its ultimate fate, or irreplaceability. Whether registering as anticipative affect or experienced as actuality, the sense of finality or erasure felt at a place's passing can invite narratives centring on the experiencing self, extending to phases of grief and mourning (Jones 2015).

Optimistic accounts of change-in-place also exist. The possibilities of renewing a relationship with place during phases of significant social upheaval, ecological disruption, or as part of broader cultural shifts, recall appeals made for a politics of place characterized by an outward-facing attitude and an acknowledgment of the 'multiplicity of stories-so-far' 
(Massey 2005), and also speak to the kinds of conjunctive, inconclusive approaches favoured in the emergent environmental humanities (Bird Rose et al 2012). When a sense of place is turned inside out, rather than folded in upon itself, emotional geographies can be forged through extended solidarities and allegiances. Redrawing maps of loyalty and responsibility is a means to refuse the cocooning effect of regressive and defensive postures; sometimes cast, fairly or unfairly, as reactionary and nostalgic (Massey 2004). The argument follows that an appreciation of place can be refreshed through a politics of progressive localism.

If critical and conceptually driven inquiries continue to renew geography's disciplinary engagements with place, of late a wider popular revival of interest has been ignited by place-studies configured as non-fiction prose that rediscovers the triangular relation between self, page and living world (Blythe 1981; Clifford and King 1996; Dee 2018). Literary 'place-writing' (also classified and promoted as 'nature writing') has prospered as a genre in British trade publishing, generating a new literature of landscape, and celebrated modern classics with broad book-club appeal (e.g. Jamie 2005; Mabey 2005; Macdonald 2014; Macfarlane 2012; Robinson 2009). Questions of authorial voice and the politics of cultural representation in these texts have attracted review and interpretation as a form of literary geography (Matless 2009), and been the subject of interdisciplinary commentary on the role of environmentalism and the literary arts (Smith 2017). Genre-based critique continues, with critics challenging writers to communicate complex versions of eco-crisis rather than offering consensual imaginaries of a pastoral and stable countryside (Cocker 2018), and questioning the preeminence of male voices, and white, straight, abelist, middleclass experience. $^{2}$ 
The art of place-writing (Ward 2014), whether academic or non-academic in origin or orientation, can also be differentiated according to stylistic approaches that variously reflect authorial preferences for, and uses of, narrative, pronouns, points of view, registers of address and generic motifs or tropes (Lorimer 2008; Cameron 2012; DeLyser and Hawkins 2014; Lorimer and Parr 2014). Consequently, the choice and use of languages for geographical (and regional) description are undergoing reappraisal as an expressive form (Matless 2015; Riding and Jones 2016). Similarly, narrative writing that draws on the raw material of experience to produce immersive accounts, passionately attentive to place and penned in the first-person, can be interpreted as emblematic of an increasingly confessional public culture. These are not mere technical concerns. Where a new premium falls on geographical writing styled as creative non-fiction, the task at hand is one of crafting words faithful to place and dialect, in language which also knows its relation to critical theory, only without abdicating the responsibilities of ensuring accessibility for a broad disciplinary readership (for example see, Lorimer 2003; Lorimer 2006; Stewart 2007; Wylie 2009; Lorimer 2013; Lorimer 2014; MacDonald 2013; Lorimer 2015). Keenly conscious of the traditions and conventions of literary genre, it is also writing ready to utilize storytelling as an oblique form of social commentary.

Composed in episodic form, this essay represents an effort to stretch the ambition of an ongoing project. It presents a case for the renewal of a place-writing tradition in geography. Not to advance a specific theoretical perspective, rather as an effort to show how the careful fusion of chosen site, subject matter and prose style can speak a language of locality, and at once reset the wider representational project by which geographers present their proprietary feelings about place, its presumed fate and possible prospects. Asking how place-stories work, why we tell them, and what we might yet make them do, is 
to press an ancient currency of cultural exchange into renewed service, where shared environmental challenges more effectively addressed and affectively articulated. My own positioning on the inside of the particular story told is explicit. After all, I have grown older alongside the place of which I write. Embedded in that relation are interrelated geographies of memory, emotion, intimacy, creativity and responsibility. At the risk of preempting the narrative yet to unfold, this is an essay that also experiments with the parable and the fable as story archetypes and which, at its close, considers the merits of sentimental feeling in an era of accelerated climate change.

\section{Dead and buried}

'I meant to write about death, only life came breaking in as usual.'

(Woolf, 1922: 42)

The Keeper was already hard at it. Busy with the dead. He'd taken the call first thing, agreed on a time, then set to, readying things for another final journey, to a farther shore.

- "Forenoon's easiest for burials. Quieter, ken."3

The words wheezed out of him as he shoveled sand higher on either side of a new hole in the ground. I peered in, catching the clean, mineralised scent of freshly turned earth. Straight-cut, the exposed sides had a pretty profile, munselling from pinky-beige nearest the surface to deeper yellows that marled into dank browns on reaching the compacted soilier depths. He sized things up. 
- "Jist a wee thing they say she is. A chow. No" much more than a pup. Ran onto the road, scared by a bigger dug. Car niver even stopped. Fair upset they sounded." ${ }^{4}$

Our look parted. I mimicked the turn of his head, gazing seaward, allowing us a brief middledistance moment. One quick flick of his chin snapped us back.

- "They two paving slabs want shifting." 5

We shuffled our way up the slope, me the head of the pantomime-horse, The Keeper its rear-end, slowly easing the stone to the ground as we came level with the graveside.

- "What's with these anyway?" I asked.

- "Bloody badgers! Efter the meat. Cannae hae open graves. Means you hae to go deep, then lay these ower the top o' things when aw's done. Wurst o' it is, thirs ither swicks, thit'll rob the slabs. Fir using in thir gairdens! Some folks eh? Steal the skin aff yer shite so they would." ${ }^{6}$

The burial site is spread across a parcel of reclaimed ground, plots landscaped into gently graduating slopes. When seen from the cliff-top above, or the vantage point afforded by rocks accessible at low tide, the fanned-out shape of a scallop shell is revealed. Closer-to, gravestones confirm what might easily be guessed at: former four-legged friends crowd the scene. The memory of dead dogs: Mac, Max, Clyde, Rex, Buddy, Mutley and Tyson. Almost as many cats jostling for position: a number of Tiddles, several Tiggers, alongside Smokey, Misty, Baby, Princess, Snowflake. And one Pussy Galore. Smaller burial spots keep the cartoon foes apart, in-filled with a carnival of other animals: hamsters, rabbits, tortoises, turtles, budgies, mice, ferrets, guinea pigs and goldfish. There's Coco. Sooty, Skippy and Sandy. Patch and Bracken. Mowgli and Lucky. Ricky. Petra. Finn. Thumper. Yoda. One 
thousand and one tales of devotion and loss, love and death, embedded within the single story unfolding here.

Not so much a place of death, rather a site in which death is placed. Natural burial and picturesque disposal set by the unsteady measure of the broken heart, a psychic landscape in miniature. Some of the funereal art is professionally engraved, with tender messages inscribed on dressed stone. Other grieving owners use roofing slates and heartshaped shoreline cobbles, with hand-painted parting words, or farewells left in splashy children's art. All plots are ornamental, in one-way or another. Prayer flags rise amidst an assortment of pet-paraphernalia, trinkets, knickknacks and bric-a-brac. A menagerie of scaled-down model animals and effigies attend the gravesides, some standing guard, others at play or rest. Fairies hover, suspended in thimble-sized bell jars. There are faded memorial wreaths, never-to-wilt plastic posies and single stem roses bent with movement and age. Pinwheels spin and ribbons flutter in a memorial kingdom where the synthetic clutter rises only ankle-high: ice-lolly stick crosses, battery-powered votive candles, favourite toys, gnarled chew sticks, tributes recycled from food bowls. Scatterings of artificial gemstones are a popular finishing decorative touch. Cobalt and teal, emerald, aqua, ruby and amber, diamond and teardrop, sent radiant in the coastal light.

\section{Night of the living dead}

'Where there is sorrow there is holy ground'

(Wilde, 1905: 29) 
My first encounter with the pet cemetery left me baffled by its sheer improbability. I stumbled into it after nightfall, as a squall blustered along the coast. ${ }^{7}$ We had arrived at the rental cottage for an autumn break. Family car unpacked, l'd gone out night walking. Stoking my melancholic side, getting a feel for somewhere new. Beyond the streetlights' sodium glow, my head-torch illuminated a strip of strangeness, just a few feet above sea level, barely a pebble toss back from the thundering breakers. Wrenching the beam from beneath my feet, I sent its sweep wider, revealing wave after wave of gravesites, reaching inland to the lee of the cliff. Hunkering down to take in each new memorial and relic, half in wonderment, half perturbed, I turned the spotlight on salt rimes encrusted into the sad unblinking eyes of plasterwork spaniels, and studied the wind-weathered coats of miniature replica border collies; now dusting off the ruins of plots that lay semi-submerged, garlanded with sea wrack; now squinting to make out blotchy handwriting and digital print photos, tearing up with condensation trapped behind glass and cellophane sleeves; now smiling at the sight of a pair of hedgehog sentry-statuettes posted, Sphinx-like, atop a short stairway. Minutes before midnight, my skin prickled with morbid thoughts of what was interred beneath my feet, and at the idea of being outflanked on all sides by species other than my own, forming an under-presence, a concealed otherness, and a hidden dominance. The whole site seemed charmed into a paradoxical state: of makeshift permanency, or perhaps a fantasia of ruination. I read it as an apparition, seemingly cast adrift from some other distant story, which by way of the turning tides, had made landfall here, misplaced and outof-time.

The morning after the night before, at the newsagent's store up in the square I posed all the obvious questions, anxious to get the creation myth. Answers came quick, 
directions easy to follow. None of the false trails that enable the storyteller to execute a series of entertaining false starts and wrong turns. I would find the man I needed to talk to by retracing my steps straight back to the property next door to the holiday house.

The Keeper and most of the townsfolk are on first-name terms. A "weel kent face" he spent his working life as a "scaffy" keeping the streets well swept, clear of litter carelessly dropped. In his youth, an apprentice-boy to the dairyman, he did the delivery round by horse and cart. Veteran status leaves him as eyewitness to the port's industrial past, when decent catches were still the mainstay of the local economy and community life. Cod wars and EU fishing quotas did for that version of the seafaring world. Dark days, he recalls, when drink got the better of trawler skippers, sometimes of him too. In retirement, there's security in familiarity. A personal commitment to orderliness hasn't diminished. He combs the beaches, occasionally drops creels for crabs and lobsters, and tends daily to the cemetery. That work began in 1992, with a spaniel's burial, as a favour done for the local doctor. "Jist potterin'”, as The Keeper describes it, has become a quarter-century habit, and one that demands a regular round of tasks. Cutting back the coarse sea-grasses that flourish on all sides of the trim enclosure. Repairing the brickwork and shallow terracing. Brushing away the shifting sands that encroach during the wildest weather. It was he who levelled the paths, setting down the paving stones, building steps and installing handrails to ease the passage of funeral parties and elderly mourners. Each internment is meticulous, nothing left in view to offend the eye. Flesh and bone, fur, feather and filth, all put safely under. Above ground, evidence of caretaking takes on differing appearance. Inscriptions on the earliest headstones are now all but indecipherable. The faces of the oldest ornamental animals are scoured beyond recognition, paintwork gone and plastic perished. What looks like neglect is in fact a courteous show of respect. Abandoned plots are sacrosanct, not to be cleaned or 
touched up. Part of the place's enigma is how it has come to resemble its founder, as if a map of one man's character. The pet-necropolis is both municipal facility and crossover kingdom, run out of kindness, a sense of public service, and a lifelong commitment to keeping things spick and span. Self-appointed steward for the life everlasting, The Keeper's cemetery is, by one reading, an act of auto-geography. Expanding at the edges, slowly deteriorating at its centre.

By a different interpretation, The Keeper is more custodian-groundsman than he is curator. He offers no codified style guide to the bereaved. A preference for absolute freedom of expression means that the pet cemetery's patterned ground is resistant to easy or comfortable categorisation, and endlessly readable. It could be located alongside the sculpture-park or environmental installation, and it holds certain affinities with open-air sites of contemporary landscape art. It might conceivably be seen as an homage to earlier styles recognized in art history. Baroque and rococo spring to mind. Surrealism too. Or, given the gaiety of the scene Pop Art; a staple of seaside culture. Personal touches and creative experiment add to the site's staged drama. Its sense of spectacle heightened when adventurous or avant forms of commemoration are juxtaposed accidentally with those reflecting more conservative tastes in the material culture of death. The consumer economy contributes to the bricolage. Many of the icons and grave goods retail at out-of-town Home \& Garden Centers: lawn ornaments; picket fencing; mini-parasols, tiny-gazebos; squares of wood-decking; and, varieties of sea-grasses and flowering heathers tolerant of salt-spray. Yet the cemetery's principle function is not so much artistic and rather mnemonic. As a space for contemplation, the Garden of Remembrance offers certain parallels, with its formal landscaping and signature features dedicated to the memory of persons who have passed on. Crucially, as a meaningful statement, the cemetery is not the expression of an 
individual blueprint, of architectural mastery or a single heroic genius. Instead it is the product of so many disparate hands, each intervention incremental, leaving a small but significant legacy. The aesthetic is uncommonly associative and accretive, largely anonymous and slow blooming.

If the cemetery exhibits a distinctively non-metropolitan culture, existing labels of appreciation - 'outsider art', 'folk art', 'low art' and 'found art' - offer an awkward fit. Each frames the site with a discerning air of connoisseurship, and can, if applied too forcefully, narrow the intent, even the agency, afforded to the maker's eye or hand. By this route, status and significance are foreclosed, and at worst, working class culture subject to 'the enormous condescension of posterity' (Thompson, 1963). The 'unsophisticated arts', a term coined by British post-war author and designer Barbara Jones' (1951) was intended to pay tribute to the unselfconscious art of the everyday. She observed it in the material world of fairgrounds, high street shops, tattoo parlours, seaside piers, amusement arcades, and funerary culture. Unsophisticated art forms were Jones' consuming passion resulting in Design for Death (Jones 1967), a notable cultural survey of methods of disposal and commemoration, encompassing death rituals, fashions and artifacts in the Anglo-American world. Jones' illustrated book of death functions as my field-guide for the vernacular creativity exhibited in the pet cemetery. It is a sustaining source, offering lessons on how to see stubbornly, scrambling any residually conservative habits of mind: enjoy lavishing the attentions of art where they are least expected; entertain rather than attack the 'pathetic fallacy' that wills personhood onto animal companions; know that to see artificiality, incongruity or idolatry alone is to throw a cloak over sincerity; learn the many giddying displays of joy and grace in the gimcrack; understand the full costs that come from judgments of value or worth crudely indexing culture against class. 


\section{'They being dead yet speaketh'}

'The death of a beloved is an amputation.'

(Lewis, 1961: 42)

In this dominion of the dead (Harrison 2003) the journeyer travels without maps. There is neither a webpage nor printed guidebook readied for consultation in advance of your visit. No on-site interpretation panel awaits your arrival. There isn't a taxonomy that fits this animal kingdom. Good reason has yet to be found to chart the full layout of gravesites; the closest thing to a sitemap trails away unfinished over a double-page of my field notebook. For long spells, the cemetery seems to have slipped the attentions of local planning and public health departments. The place is countercultural, its procedures pre-digital, animal remembrance the stuff of a modern stone age. The burial business remains unprofessional. The Keeper takes requests over the phone, or by post. He selects a plot, digs the grave, meets with the loved ones, and then conducts the internment of the carcass. Over the years, he's had to bury two of his own. The graves for Bruce I and Bruce II are patriotic affairs. The lifetime of each Alsatian landmarked with a painted blue saltire.

Good manners tell us not to intrude on private grief, but I also know it's possible to listen out for the peopling of the cemetery-as-place, developing an ear for its small talk, 
overheard in snatches, and whispered graveside greetings. The voices have a tendency to scramble subjectivities:

\section{- "Atsma Boy" \\ - "Good Lass"}

Whose hair is being ruffled here? With your back turned, registers of address, and the recipient of parental affirmatives or affectionate expressions, might just as easily be companionably human as animal. Other talkative tributes further contort the family tree.

- "Loved him like a brother, so I did."

- "Whit a wee sweetheart. Ended up closer tae him than I wis ma man."10 Codependency and emotional support, it turns out, are kinds of transversal longing that don't end with pet death and buried remains. Old friendships are worth keeping real, but demand a proper place for the petting of sorrows, for the exquisite agony of pleasureable suffering, where it's okay to return and keep on saying goodbye.

For human burial, Christian custom demands that stone inscriptions are kept short, the expense of the engraver's craft probably having something to do with this too. The lettering is reserved, reflecting decency and taste. Perhaps that explains why l've always found headstones so curt and cold-shouldered. Necrogeographical research has, to date, attended to the cultural landscapes, architectures and infrastructures that humans design for one another (Laqueur 2015; Maddrell and Sidaway 2010). Sites the likes of the porttown's kirk graveyard, located on the headland directly above the pet cemetery. It presents object lessons in form. Lives once lived, tightly circumscribed by the parish bounds, are cupped between dates of birth and death, in the year of Our Lord. Thin-lipped praise is raised to a familial role fulfilled (sister, wife, mother), and notice given of those closest, left bereaved. Very occasionally, a fitting epitaph has been chipped out. And that's it. 
But when it comes to dead pets, the language of love slips the leash, runs unmuzzled. So the pet cemetery is full of...gush. Appreciation is voiced for devotion, obedience, rascality, warmth, trust, sacrifice, affection, bravery, nobility, honour. And simply: for companionship. Parting words are chipped out in Doric, corner dialect of Scotland's northeast, so that fingertips can lovingly trace the lettering. Hewn from granite, language is unmistakably a material thing. The grief poetry follows a couthy grain:

- "Pepsi. Oor wee quinie, gone for a walkie".

- "Scamp. Awa Hame. Love Mither and Fither."11

Generally speaking, the praises raised to best friends are heart gladdening, placing the pet inside the personal. Sincere tributes seldom make many demands on the imagination. Akin to a lazy, fireside stretch: 'I knew love. I knew this dog'. Separate selves curl up together, giving different shape to life, becoming the stuff of acceptable intimacy and soft familiarity. Read boldly, they are not two beings, but two aspects of a being. Or, more cautiously, express what it is to feel close and yet distinct, to wish to enter the other, but be held apart by the limits of imagining life in another body. Stroke and scratch. Paw and purr. Bark without bite. Gentle peck and nibbled collar. Wet hair and warm nuzzle.

Certain patterns of words succeed in distilling a relationship to the quintessence of true love: 'Spey: 1990-2005. Oor Auld Man. Sadly Missed.' Where epitaphs appear, they mark the late stages of the healing process, when mourning is recognised as therapeutic, sometimes with spiritual inspiration: 'Dog is God spelled backwards'. Some rehash the sayings and standards of sympathy cards. There's the occasional commendation that's richly comic, reflecting the bleak humour of the funeral parlour: 'Aris. Beautiful black cocker spaniel taken too soon by her love of the water. Leaves behind great holes in our hearts, and garden.' Death, the pet headstone reminds its reader, is sometimes an absurd 
pantomime of surprises. You might be left dewy or dry-eyed. And then there are tributes still so burdened by sorrow, pain and unendurable emptiness they are likely to rend a stranger's heart asunder:

- “Cleo. Oh ma bairn."12

The founding question of the animal applies equally to every parting word. Earlier efforts to re-shape social theories around the inter-subjectivities emerging between domestic pets and human pet-keepers, have been directed at differing ethical-political projects, concerned variously with: the dominance and subjugation that must be fused with affection to enable the infantilisation of animals (Tuan 1984); addressing issues of power and priority through a fuller recognition of canine emotional intelligence (Haraway 2003); critiquing new libidinal economies of pet-keeping (Nast 2006), of a sort epitomized in the fashion for dog-breeds like the "teacup Chihuahua"; and appreciating the cultural necessity of mourning (DeMello 2016). Such advances in the configuration of animal studies and critical pet studies acknowledged, in essence and experience the pet remains forever a sentimental concept. This realisation can be disconcerting, since sentimentality is a sensibility seldom subject to close inquiry. It is the structure of feeling no self-respecting critical geographer should make time or space for; since it is commonly judged much too soft-headed to take seriously. Quick or easy dismissal can inadvertently undermine the claims made for 'emotional geography', as an emergent field of study permitting a greater range of academic expression and empathic registers of address. Stewart (1992) closes the gap between the critical and the sentimental, in an analysis of 'miniaturism' as a cultural and material form: 'The transcendent presented by the miniature is a spatial transcendence which erases the productive possibilities of understanding through time. Its locus is thereby the nostalgic.' (Stewart 1933: 60). Cultural critic and essayist, Leslie Jamieson (2014) pushes 
a case for the unforgiveable sensibility further still, quipping that if sentimentality is the word people use to insult emotion - in its simplified, degraded and indulgent forms - then "saccharine" is the word they use to insult sentimentality.' These arguments have local purchase at the pet cemetery. Memorialized by miniature replicas, former pets are always angelically present. Their bad habits ever forgiven: no messes and puddlings, no awful smells or scratched furniture, no lust, gluttony, aggression, resistance or sloth.

\section{Family fortunes}

'Death is the sanction of everything the storyteller can tell. He has borrowed his authority from death.'

(Benjamin, 1936)

Like any writer worth his salt over the years I've become adept at aligning the accidental with what is willful. In the right company, I'll confess to twinning good deeds or family outings, with larval ideas forming for a possible future essay. So when our pet hamster died there was really only one place he was ever headed. Peter had entered our lives two and a half years before. His relocation from the local pet shop window into our small flat marked the occasion of our son's fifth birthday. He took up residence in a three-story cage complex, big enough to quell my feelings of guilt about animal entrapment. So grand in fact that it loomed over the dinner table, making Peter an ever-present guest at mealtimes. But, hamster and child never quite hit it off. Too many nervy nips and bites for a proper bond to 
build. And so, as is so often the way of things, daily duties of pet care became another parental responsibility. Moments of bonding, when they happened, tended to follow predictable kinds of domestic mishap. An escapist streak had Peter depart his cage unsupervised on at least two occasions. The longest misadventure lasted five days. Eventual relief and family reunion only brought about after the desperate purchase of a humane rattrap.

Nevertheless, with Peter's passing, there was a shared sadness and sobriety about the midwinter car ride out from the city. Snow gathered beneath the roadside hedgerows. A northerly wind scoured us, making noses drip and eyes water prematurely. Frost stiffened the sand underfoot. The Keeper wasn't sure he'd be able to break through the bone-hard top. But a gravedigger worth his salt can handle a shovel. The hole dug for Peter was of sufficient depth; echoing Seamus Heaney's verse, one foot for every year. Work done, still a little breathless from the effort, The Keeper took a couple of steps back, head lowered respectfully, exhibiting a sense of occasion and discreet feel for ceremony. Then we consigned our family hamster to the earth, his perfect-fit coffin a smooth-sealing box for an iPhone 4. With the grave back-filled, we put our painted and varnished headstone in place, then lined the edges of the plot with foreshore pebbles. Our son placed a single tulip of thanksgiving.

For man, as for boy, mortality is a lesson never fully learned, and in the weeks afterward with events still fresh, the direction of my thoughts drifted, unexpectedly and sentimentally, to the small seaside spot he now occupied. But of course, with time, feelings fade. For a long spell, I'll confess to having given little thought to Peter; that is until beginning to put down the words that you are reading now. 
'To see oursels as ithers see us!'

'These fragments I have shored against my ruin.'

(Eliot, 1922: 59)

That I don't explain myself is no sly deceit. There's just never been any indication that I should. No questions get asked about the nature of my interest. No gathering impression conveyed that by occasionally showing face I might harbor any greater purpose. The occasional mention that I've made of a writing project emerging gained no traction. Small talk has been revealing, in the ways that it can be. Gentle chitchat really. At times I'm the city-dwelling holidaymaker, and on occasion nothing more than a passer-through. Certain weekends I get figured as that "young laddie's faither". Other times the keenest of cemetery-photographers. And once or twice I've been conscripted as helping-hand or heavy-lifter. But in all the passing years, I don't recall The Keeper ever asking me for my name. For him, the simplest of greetings suffices.

- "Awright $\min ? " 13$

One Monday morning in March, I showed up unannounced, deadened by deskwork, but liberated by the forecaster's promise of early spring weather. The sun hadn't crested the cliff-top as I parked. Cold air drew a clear line between sea and sky. The Keeper was there already. Back turned, preoccupied. He was fiddling with the underside of a miniature ornamental lighthouse. The hinged plastic flap for encasing the battery compartment 
wouldn't quite close. I offered to have a go, fingertips still carrying the car heater's warmth. Slipped into position, the flap fell flush, clicking shut. The tiny bulb blinked into life, and the clever wee contraption began its slow revolve. I handed it back. He fixed the upper section onto the lighthouse base, standing sentinel over the grave of his oldest friend [Bruce I, $23^{\text {rd }}$ June $1981-10^{\text {th }}$ March 1994]. We stood admiring the faint halo of light it cast.

- "Right." he said, satisfaction evident. "Now Bruce'll be able tae read his paper at night."

All of a sudden there was weightlessness in the moment. Not brought on by the earliness of the hour. And not just the comforting sense that can come from turning back the clock, so that the present might bathe in the serene waters of the past. But a fidelity in the imaginary, of a sort I was unprepared for, and had no words ready. Right there, a magical view of the world, taking shape in life and death, the order of things being reset, the full circle of it all given different meaning. Perhaps what it was remains unsayable yet. A look of tenderness stole across his features, softhearted feelings that I was awkward to have him see me see. So I stared down, shuffled about a bit, before shooting my gaze heavenwards.

Thousands of feet above us a passenger plane was careening north, underside glinting silver, contrail parting the blue. His eyes joined mine.

- "Yon toon bypass is still daen a guid job eh?" he deadpanned. ${ }^{14}$ Levity re-tethered us. Safely earthed, we walked on, in league with one another, a kinship of sorts. Along the shoreline path far enough so he could show me a sturdy tree-trunk, ends perched on two rocky outcrops, as if left out of mischief by the ebbing tide. A river washout so he reckoned.

- "Some lads is comin' doon wi' saws. Takin' the lot awa' the-night."15 
Talk of the sea's bounties got me thinking. I'd half a mind to angle for an invite to Tigh na Mara, his shorefront stockade. ${ }^{16}$ Cold calling isn't advisable. Bruce III guards the property jealously, barking at shadows, night and day. The place is different parts stronghold, storehouse and sanctuary. Foursquare, whitewashed, it has a walled-in yard, with upright smokehouse for curing racks of fish, and a wooden shed sheltering a notable picture gallery of old street and seaside scenes. He had toured me around the private collection of prints, photocopied images and souvenir postcards several times before, ably performing the role of hometown historian and tour-guide. But what I wanted more than anything was the chance to refresh a remembered inventory of the beachcombing treasures cached in the upstairs chamber. To rename its things.

There had been one earlier visit. Years before. A minor wake of sorts, held right after Peter's burial. We'd signed The Keeper's Book of Remembrance, but mostly spent time marveling at the surrounds. I can recall the sharp tang that clung to everything, a blend of tar and turpentine, seaweed sulfur and shellfish innards. Not unpleasant: the seasoned, ingrained sort of smell I imagine a mariner's chandlery might have. The two adjoining rooms were uncarpeted, sparsely furnished. A narrow box-bed, sheets and blankets folded back tight, two-bar electric fire and radio-set off to the side. Framed watercolors hanging from picture-rails, stock images of seascapes: ocean-going craft, rigging in full sail, white horses brimming at the surface. Things had a semi-lived in look. The interiors sent murky and grainy, as the pearly-grey light of a winter afternoon called it a day.

From memory, images can be summoned of spoils from the sea consuming all available surfaces. Over the floor, and across workbenches, were coils of rope-quayside thick and frayed thin - rusted hooks and fluorescent buoys, a corroded metal nameplate among other oddments salvaged from a wreck. Vessels of all sizes, stoneware in differing 
styles. Lobster pots and chamber pots, an array of tilly-lamps hanging from wall-hooks.

Driftwood set up to show interesting aspects, baskets and biscuit tins brimful with cowries and crab-shells, sea-potatoes and sand dollars. Wooden crates on dresser tops, sills and mantle, piled high with animal bones, shapely pebbles, bottle-tops, sand-smoothed glass fragments, the feathers and skulls of shorebirds. The otherness of gulls' eggs.

- "Dinnae taste ower bad", I half-heard him murmur. ${ }^{17}$

The entire place followed an organizing principle that was The Keeper's very own. A maritimer's wunderkammer, his sea inside (Hoare 2014). Amongst all possessions, a pair of gift boxes was given pride of place. Originally housing men's tailored shirts, the stiff cardboard now badly dented, when slid open they revealed locks of hair. Keepsakes of Bruce I and Bruce II, we were told. A deathbed palette: sepia and sandy tones twining with the salt and pepper of old age. Not a lustrous fleece. Tired looking tufts, tangled and matted. Some rolled into balls from repeated handling.

Considering lives spent at the littoral edge, and the character or creativity afforded to artwork by coastal geography, Harris (2009: 228) suggests that 'displays of orderliness in the face of the elements' are 'a humble but remarkable form of resilience'. Such ritual ordering can be exhibited extensively, as work and as hobby, on home ground and garden, in the life of the mind and as lived culture. The Keeper's own art of place-making finds its fit among celebrated practitioners the likes of Derek Jarman and Ben Nicholson for whom neatness counted. It shares a commitment to keeping things ship-shape, providing commonplace standards and underlying truths. But these events were all back in the day of course. Beneath a brightening sky, the very idea of wheedling my way into this interior life, and its deeper worlds, seemed all of a sudden much too much like gatecrashing. The respectful guest must be, one and the same, a calculating sort, able to gauge when the 
timing is right for a tricky request. Or better yet, to know the value of endless deferral, and be prepared to inhabit expectation or cherish the pipedream.

I turned for the car, allowing us to go our separate ways.

- "Ah'll see you later then."

The Keeper tilted his head amiably, offering the corner of a smile. Enough to hint that he knew all too well who was befriending whom, and whose longing to be possessed by place was really being fed.

- "Aye, you an' aw." 18

\section{Sic transit gloria mundi}

'Any geographic now (a landscape in its fullness, if you like) is not best understood in terms of its stable individuality, but in terms of its double face of graveyard and cradle of creation.' (Hägerstrand, 1983: 23)

As this place portrait has grown, its subject matter altered in its dimensions too. With the passing years, popularity as a patch of earth for putting pets to rest has placed a premium on plot-space. The Keeper's response was determinedly practical: clearing a meter-wide strip of unused scrubland along one side of the site's perimeter edge, readying it for future use. Breaking new ground breached an agreed but unmarked boundary, and rocked the cemetery's safe world. A cease and desist letter issued by the landowner - Seafield and 
Strathspey Estate, acting on behalf of Lord and Lady Seafield ${ }^{19}$ - reiterated the terms and conditions originally set down for the long-term lease of property, requesting an on-site inspection with The Keeper, its tenant. What then resulted was a territorial dispute, perfectly realized in miniature form.

The Keeper put the word around. Fellow townsfolk led the creative resistance, launching a campaign in defense of the cemetery, using a Facebook page as its promotional platform, and enlisting support door-to-door. ${ }^{20}$ In a matter of days, the 'Save the Pet Cemetery' petition had secured more than 1500 signatories (my own included); a mixture of local residents, self-styled representatives of a nation of animal-lovers, and sympathizers scattered worldwide. Opinion was freely shared online. The public mood: incandescent. Some, fearing the worst, understood the site's very existence to be suddenly in jeopardy. Anguished posts were left by once bereaved families, their grief reawakened, alarmed at the thought of a dearly beloved about to be rudely unremembered. Accusations of pettiness and heavy-handedness were leveled at the Estate. Its agent's alleged use of a bureaucratic language of compliance, encroachment and infringed rights was met with scorn. And amidst the hullaballoo, the precise wording of the controversial legal missive was very quickly obscured. The petitioners' defence of place was defined by a principle of exceptionalism, with appeals made that the cemetery and its faithful keeper each be treated as a one-off. Backers familiar with the local scene pressed a case for the cemetery as one of the town seafront's heritage features, and a must-see visitor attraction highly popular with strolling tourists. Property's relation to place was trumped by its perceived value as public asset. Numerous testimonials brought the politics of personality into play. The Keeper underwent saintly transfiguration: a secular Franciscan, miracle worker, and guardian angel. He was a man of 'grace', 'integrity' and 'honesty', whose custodial duties enshrined 'common 
decencies'. By way of contrast, the estate's property director was depicted as brutish, meddling, guilty of pedantry, the keeper of a hollow heart, and an enemy of individualism. The process of beatification was a headline writer's dream. The unfolding story attracted coverage and feature photographs in the regional press, then national dailies, followed finally by a television news crew. Meanwhile, depth of feeling in the local community was refracted through very specific cultural reference points. A regional history of feudal land clearance resurfaced. In the queue of customers ordering takeaway suppers at the fish and chip shop, the talk was of scores never properly settled and of not giving ground; about powerless tenants lorded over by the aristocracy, and centuries-old grievances resulting. Suspicions were aired that the site (and by implication The Keeper) had been judged too big for its boots; the kind of place that didn't know its place. Cinematic culture was re-projected too, placing the pet cemetery between worlds of truth and fiction. In Bill Forsyth's much-loved classic Local Hero (1983) the tranquility of a Scottish coastal village comes under threat when a development corporation reveals plans for a petroleum refinery and pipeline. The real film location used for the fictional village of 'Ferness' lies twenty-five miles east along the coast, visible on a fine day from the headland above the pet cemetery. In the movie, scenic disaster is narrowly averted when Mac, the Texan oil tycoon, has a last-minute change of heart, having bonded with Ben, the community's resident beachcomber cum spirit-guide. For some onlookers, the resemblance was irresistible, cinematic history aligning with local geography, The Keeper and his cemetery self-starring in a real-life re-make.

Life did imitate art in the end, at least partially so. Virtual enmities never erupted into physical ones. Vexed questions of 'cultural necrogeography' (Laqueur 2015: 179) were quietly resolved. The Keeper agreed to no further expansion without prior consultation. The 
Estate guaranteed the site's future, and a land rent continuing at the originally fixed rate of $£ 20$ per annum, while maintaining that all along its chief concern had been to safeguard the nearby 'Site of Special Scientific Interest'. The events here reported can reasonably be said to reflect what Patrick Kavanagh - a poet-novelist ever alert to poised deeds and words as the very facts of being - referred to as 'radical parochialism'. Keenly concerned with how cultural attitudes are held expressed and valued in the felt world, Kavanagh argued for a crucial spatial distinction:

'Parochialism and provincialism are opposites. The provincial has no mind of his own, he does not trust what his eyes see until he has heard what the great metropolis towards which his eyes are ever turned has to say on any subject. This runs through all his activities. The parochial mentality on the other hand is never in any doubt about the social and artistic validity of his own parish. All great civilizations are based on parochialism: Greek, Israelite, English. Parochialism is a universal and deals with fundamentals.' (Kavanagh 2003 [1952]:

Kavanagh acknowledged the risks attendant on this attitude. Put too emphatically, a language of local attachment and association can grow introverted: 'Advising people not to be ashamed of having the courage of their remote parish, is not free from many dangers. There is always that element of bravado which takes pleasure in the notion that the potatopatch is the ultimate' (Kavanagh 2003 [1952]: 238). Recent reflections on the legacies of Kavanagh's doctrine of localism keep faith in its latent radicalism (Tomaney 2012). The crafting of a regional tone, or style, even a distinctive aesthetic can be a means to realise 
fidelity to place. If that same place-relation is simultaneously open in its appeal, its values might be released, growing towards and entering into the lives of distant others.

Galvanized by the save-the-cemetery campaign, local championing of The Keeper did not cease. Effort found regional reward. In recognition of distinguished public service over twenty-five years, he was crowned winner of the annual 'Third Sector Interface (TSI), Moray Community Champion Award'. A self-effacing type, The Keeper avoided the prize-giving ceremony's limelight, instead, receiving a plaque and certificate from a party of Council dignitaries (led by TSI Moray's Operations Manager) who paid the cemetery a special visit. Rumours have since circulated of his nomination for yet higher decoration, on the Queen's New Year Honours List.

- "Stands to reason, right? Her Majesty's been a dog-lover all her life."

\section{Passing Places}

'A life becomes readable and therefore recountable when it has come to an end. Which puts the writer or the storyteller into a strange category, he is a kind off secretary of death. He is death's secretary. What he reads of course is not death, but life. He reads across that blackness.'

(Berger, 1983) 
When gains are made or losses accrue, it pays to be place-aware, resisting any temptation to downplay events - the likes of those described above - as simply another "storm in a teacup", and instead to put stock in what poet John Burnside (2015) has called 'the sensation of the specific'. Part of the recent push to protect the pet cemetery is, it would seem, an awareness of days gathering to an end, no longer beyond the horizon, unimaginable. This essay, a small gift readied for a significant anniversary, is no different in status. Approaching his eightieth year, The Keeper is without apprentice or ready successor. Tenanted land is a complex kind of bequest. And besides, the work is not yet done. There are forces greater than the landowning aristocracy persistently undermining the pet cemetery.

Tidal erosion has been the energetic sculptor of the port-town's scenery, its longest standing artist-in-residence. Waves were the maker of its defining features, and the slowmotion destroyer of its crumbling landmarks. The ceaselessness of the sea has a way of playing on the mind, the power to compel and undercut. Back then forth, wipe and reveal. Back then forth, wipe and reveal. Childhood fears that the flood tide will just keep on coming, getting ever hungrier, are no longer quelled in adult life. Climate science models predict a sea of troubles ahead: bigger waves, higher levels, storm surges, strange tides, all that stuff of excesses and extremes. Geomorphology compounds the problem. This stretch of Scotland's coastline is subject to isostatic subsistence: the edge of the land is lowering as the sea is rising. If the nature of the threat faced remains uncertain (according to its geography, timing and severity), what is beyond doubt is that the neck of land separating the pet cemetery from the North Sea is getting scrawnier. Last year, the buffer could be crossed in half a dozen strides. A recent winter storm ate more of it away, cutting the distance to little more than four..$^{21}$ 
Ultimately, this place seems destined to be consumed by itself, incapable of holding back the tidal forces that have daily been part of its scenic drama. When the under-cliff eventually slips, culture's calamity will come away with it, a biomass of bleached bones and animal body parts sloughing out in the backwash. And the rising sea will be recast as body snatcher and watery grave. Rather than figuring this as an unfortunate case of the wrong stuff in the wrong place at the wrong time, a near-future imaginary of the cemetery's fallen angels ought to prove more generally telling. This speculative prospect can serve to scramble what we judge as 'grievable lives' (Butler 2010), where the departing glories of domestic life represent an unexpected alt-ecology, one all the more striking for its contrast to the popularized plight of the living world at the polar icecaps. My pet premonition is just as alienating to imagine, and arguably more complex because it is so deeply uncanny. By these terms, sentimentality is drawn into a wholly different sort of service: the re-writing of wholly unnatural coastlines.

How might this pet theory play out for the greater prospects of place? The cemetery might be figured as one in any number of messenger places; mindful of a longer maritime history of brilliant beacons, SOS distress signals and bottled messages retrieved from the sea. Passing places is my preferred term of reference, seeking to capture a swansong character, readied for entry into contemporary mythology. Picturing the pet cemetery as a visionary place seems entirely reasonable. To stew here long enough is to invite what Joseph Mitchell (2012) - celebrated folklorist of place - memorably described as 'a graveyard cast of mind'. This affective state is not exclusive. If minor places are imperiled all over, then unexpected solidarities can be found in painful recognition, and a planetary plight shared (Garrard et al 2014; Carpenter 2016). Aldersley-Williams (2016; 18) crystalizes the predicament: 'Half of the world's population lives in coastal regions lapped by tidal 
waters'. It has been suggested that the reality of place-loss increasingly associated with life in the age of the Anthropocene produces a distinctive condition. 'Solastalgia', by Albrecht's (2007: 95) original definition, is a 'form of psychic or existential distress caused by environmental change', and potentially diagnosable. Anticipatory losses, likely to be incurred in the near-future, might register at the level of qualia - the ghosts of subjective, conscious experience - or as a more widespread community response to irrevocable change altering the appearance or character of a locale (Cunsolo and Ellis 2018). Planning for inundation and managed retreat on stretches of the British coastline is already inviting contrasting kinds of cultural response (Matless 2016; 2017). Public expectation that protective measures or ameliorative action will be taken, nowadays are met with responses from environmental agencies and land-owning charities that ask challenging questions about efficacy, value and relative worth. Advocacy for greater acceptance of coastal change - based around a recognition that scenic heritage can enter into a phase of 'palliative curation' is intended to enable communities better to cope with the impacts of loss, and manage the grief resulting (DeSilvey 2014; 2017). By these terms, place's last extended exhalation will be something that we dwell on, as much it continues to be a phenomenon we dwell in.

Like the myth-making figures of Noah, Canute and Jonah before him, The Keeper is fallible. Rhetorically speaking, the political stakes of his local lifeworld are all the more powerful for acknowledging this mortality. His story is shadowed by the parable, an ancient didactic form of telling, whose characters provide the listener with instructive lessons and principles on the human condition, and the fable, where animals, objects and forces of nature are afforded pivotal roles in any plot. The pet cemetery - and its parochial geographies of memory, emotion, intimacy, creativity and responsibility - must speak for 
two ages: the remembered past, of course, but also a past now being rewritten in the name of the future. The upshot of facing both ways is that the traditional gravestone epitaph Hic jacet [Here Lies...] is rendered a provisional rather than a final statement.

In much the same fashion as we remember exactly where we were when reading something significant, readers might recall this particular spot when lighting upon the future of passing places that matter as much to them as the pet cemetery does to The Keeper.

\section{Acknowledgements}

This essay was very slow to grow. Prototype versions benefitted from the generous attentions of diverse audiences in Ardtornish, Edinburgh, Exeter, Glasgow, Hull, Kingston, London, Manchester, Melbourne, Sydney and Tartu. I am grateful for the comments provided by journal editors and reviewers, and the careful reflections offered by Ursula Lang on a working draft. And, of course, I'm thankful for time spent keeping The Keeper's company.

\section{References}

Albrecht, G. (2007). Solastalgia: the distress caused by environmental change. Australas Psychiatry, 15, 95-98. doi:10.1080/10398560701701288

Aldersley-Williams, H. (2016). Tide: the science and lore of the greatest force on Earth. London: Viking.

Assessments and Qualifications Alliance. (2016). A-level geography specification. Retrieved from http://www.aqa.org.uk/subjects/geography/as-and-a-level/geography-7037 Benjamin, W. (1936) [1968]. The storyteller: reflections on the works of Nikolai Leskov. In Illuminations. New York: Harcourt Brace. 
Berger, J., \& Sontag, S. (1983). To tell a story. Retrieved from https://www.youtube.com/watch?v=MoHCR8nshe8

Bird Rose, D., van Dooren, T., Chrulew, M., Cooke, S., Kearnes, M., \& O’Gorman, E. (2012). Thinking through the environment, unsettling the humanities. Environmental Humanities, 1(1), 1-5. doi:10.14361/transcript.9783839421352.fm

Blythe, R. (1981). Places: an anthology of Britain. Oxford: Oxford University Press.

Burnside, J. (2015). Skellig Michael is hardly an island - but it's the one I love the most. New Statesman, https://www.newstatesman.com/culture/nature/2015/09/skellig-michael$\underline{\text { hardly-island-it-s-one-i-love-most }}$

Butler, J. (2010). Frames of war: when is a life grievable? London: Verso.

Buttimer, A. (1976). Grasping the dynamism of lifeworld. Annals of the Association of American Geographers, 66(2), 277-292. doi:10.1111/j.1467-8306.1976.tb01090.x

Cameron, E. (2012). New geographies of story and storytelling. Progress in Human Geography, 36(5), 573-592. doi:10.1177/0309132511435000

Carpenter, J. R. (2016). Writing coastlines. Performance Research, 21(2), 12-16. doi: $\underline{10.1080 / 13528165.2016 .1162520}$

Casey, E. (1998). The fate of place: a philosophical history. California: University of California Press.

Clifford, S., \& King, A. (1996). From place to PLACE. Devon: Common Ground.

Cocker, M. (2018). Our place: can we save Britain's wildlife before it's too late? London: Jonathan Cape.

Cresswell, T. (2004). Place: a short introduction. London: Wiley-Blackwell. 
Cresswell, T. (2012). Value, gleaning and the archive at Maxwell Street, Chicago.

Transactions of the Institute of British Geographers, 37(1), 164-176.

doi:10.1111/j.1475-5661.2011.00453.x

Cunsolo, A., \& Ellis, N. (2018). Ecological grief as a mental health response to climate change-related loss. Nature Climate Change, 8, 275-281. doi:10.1038/s41558-018$\underline{0092-2}$

Dee, T. (2018). Ground work: writings on people and places. London: Jonathan Cape.

DeLyser, D., \& Hawkins, H. (2014). Introduction: writing creatively-process, practice and product. cultural geographies, 21(1), 131-134. doi:10.1177/1474474012469006

DeMello, M. (2016). Mourning animals: rituals and practices surrounding animal death. East Lansing: Michigan State University Press.

DeSilvey, C. (2017). Curated decay: heritage beyond saving. Minneapolis: University of Minnesota Press.

DeSilvey, C. (2012). Making sense of transience: an anticipatory history. cultural geographies, 19(1), 31-54. doi:10.1177/1474474010397599

Eliot, T. S. (1922) [2007]. The Waste Land and other poems. London: Dodo Press.

Feigel, L., \& Harris, A. (2009). Modernism on sea: art and culture at the British seaside. Oxford: Peter Lang.

Garrard, G., Handwerk, G., \& Wilke, S. (2014). Imagining anew: challenges of representing the Anthropocene. Environmental Humanities, 5(1), 149-153. doi:10.1215/22011919$\underline{3615451}$

Hägerstrand, T. (1983). In search for the source of concepts. In A. Buttimer (Ed.), The practice of geography. London: Longman. 
Haraway, D. (2003). The companion species manifesto: dogs, people and significant otherness. Chicago: Prickly Paradigm Press.

Harris, A. (2009). Seaside ceremonies: coastal rites in twentieth-century art. In L. Feigel \& A. Harris (Eds.), Modernism on sea: art and culture at the British seaside (pp. 227-244). Oxford: Peter Lang.

Harrison, R. P. (2003). The dominion of the dead. Chicago: University of Chicago Press. Hoare, P. (2014). The sea inside. London: Fourth Estate.

Hubbard, P., \& Kitchin, R. (2011). Key thinkers on space and place. London: SAGE. Jamie, K. (2005). Findings. London: Sort of Books.

Jamieson, L. (2014). The empathy exams. London: Granta.

Jones, B. (1951). The unsophisticated arts. London: Architectural Press.

Jones, B. (1967). Design for death. London: André Deutsch.

Jones, O. (2015). "Not promising a landfall...": an autotopographical account of loss of place, memory and landscape. Environmental Humanities, 6(1), 1-27. doi: $\underline{10.1215 / 22011919-3615880}$

Kavanagh, P. (2003) [1952]. The parish and the universe. In A. Quinn (Ed.), A Poet's Country: Selected Prose (pp. 237). Dublin: Lilliput Press.

Laqueur, T. W. (2015). The work of the dead: a cultural history of mortal remains. Princeton NJ: Princeton University Press.

Lewis, C. S. (1961) [2015]. A grief observed. London: Faber.

Lorimer, H. (2003). Telling small stories: spaces of knowledge and the practice of geography. Transactions of the Institute of British Geographers 28(2), 197-217. doi:10.1111/1475-5661.00087 
Lorimer, H. (2006). Herding memories of humans and animals. Environment and Planning D: Society and Space 24(4), 497-518. doi:10.1068/d381t

Lorimer, H. (2008). Poetry and place: the shape of words. Geography 93(3), 181-2.

Lorimer, H. (2013). Scaring crows. Geographical Review, 103(3), 177-89. doi: $\underline{10.1111 / g e r e .12007}$

Lorimer, H. (2014). Homeland. Cultural Geographies, 21(4), 583-604. doi: $\underline{10.1177 / 1474474014547335}$

Lorimer, H. and Parr, H. (2014). Excursions: telling stories and journeys. Cultural Geographies, 21(4) 543-47. doi:10.1177/1474474014547326

Lorimer, H. (2015). Standards of beauty: considering the lives of W.A.Poucher. Geohumanities: space, place and the humanities, 1(1), 51-79. doi: $\underline{10.1080 / 2373566 X .2015 .1068667}$

Lowenthal, D. (1961). Geography, experience, and imagination: Towards a geographical epistemology. Annals of the Association of American Geographers, 51(3), 241-260. doi: $\underline{10.1111 / j .1467-8306.1961 . t b 00377 . x}$

MacDonald, F. (2013). The ruins of Erskine Beveridge. Transactions of the Institute of British Geographers, 39(4), 477-489. doi:10.1111/tran.12042

Macdonald, H. (2014). H is for hawk. London: Jonathan Cape.

Macfarlane, R. (2012). The old ways. London: Hamish Hutchinson.

Mabey, R. (2005). Nature cure. London: Vintage.

Maddrell, A., \& Sidaway, J. (2010). Deathscapes: spaces for death, dying and remembrance. London: Routledge.

Massey, D. (2004). Geographies of responsibility. Geografiska Annaler B, 86(1), 5-18. doi: $\underline{10.1111 / j .0435-3684.2004 .00150 . x}$ 
Massey, D. (2005). For space. London: SAGE.

Matless, D. (2009). Nature voices. Journal of Historical Geography, 35(1), 178-188. doi: 10.1016/j.jhg.2008.12.012

Matless, D. (2015). The regional book. Axminster: Uniformbooks.

Matless, D. (2016). Climate change stories and the Anthroposcenic. Nature Climate Change, 6, 118-119. doi:10.1038/nclimate2862

Matless, D. (2017). The Anthroposcenic. Transactions of the Institute of British Geographers, 42(3). doi:10.1111/tran.12173

Mitchell, J. (2012) Up in the old hotel. London, UK: Vintage Classics.

Nast, H. (2006). Critical pet studies? Antipode, 38(5), 894-906. doi:10.1111/i.1467$\underline{8330.2006 .00484 . x}$

Relph, E. (1976). Place and placelessness. London: Pion.

Riding, J., \& Jones, M. (2016). Introducing reanimating regions. In J. Riding \& M. Jones (Eds.), Reanimating regions: Culture, politics, and performance (pp. 1-6). London: Routledge. Robinson, T. (2009). Stones of Aran: labyrinth. London: Penguin.

Smith, J. (2017). The new nature writing: rethinking the literature of place. London: Bloomsbury.

Stewart, S. (1992). On longing: narratives of the miniature, the gigantic, the souvenir, the collection. Durham NC: Duke University Press.

Stewart, K. (2007). Ordinary affects. Durham NC: Duke University Press.

Thompson, E. P. (1963). The making of the English working class. London: Victor Gollancz. Tomaney, J. (2012). Parochialism - a defence. Progress in Human Geography, 37(5), 658672. doi: $\underline{10.1177 / 0309132512471235}$ 
Tuan, Y-. F. (1977). Space and place: the perspective of experience. Minneapolis: University of Minnesota Press.

Tuan, Y-. F. (1984). Dominance \& affection: the making of pets. New Haven, CT: Yale University Press.

Ward, M. (2014). The art of place writing. Geography Compass, 8(10), 755-766.

doi:10.1111/gec3.12164

Wilde, O. (1905). De profundis. London: CreateSpace.

Woolf, V. (1922) [2003]. A writer's diary: being extracts from the diaries of Virginia Woolf. London: Mariner.

Wylie, J. W. (2009). Landscape, absence and the geographies of love. Transactions of the Institute of British Geographers, 34(3). doi:10.1111/j.1475-5661.2009.00351.x

\footnotetext{
${ }^{1}$ https://tinyurl.com/y9chauen

2 'British Nature Writing, 1789-2014' is currently the subject of a major AHRC-funded research project. https://landlinesproject.wordpress.com/

3 "Before noon is easiest for burials. Quieter, you know."

4 "Just a little thing they say she is. A chow. Not much more than a pup. Ran onto the road, scared by a bigger dog. Car never even stopped. Really upset, they sounded."

5 "Those two paving slabs need to be moved."

6 "Bloody badgers! After the meat. Can't have open graves. Means you have to go deep, then lay these over the top of things when everything's done. The worst of it is, there's other thieves. That will steal the slabs. For using in their gardens! Some folks eh? Steal the skin off your shit so they would."

${ }^{7}$ A reality perfectly mirroring the oft-parodied opening phrase "It was a dark and stormy night..." of fiction writing cliché.

8 "Well known face"

${ }^{9}$ Scaffy: street-sweeper (Scots dialect)

10 "What a little sweetheat. I ended up closer to him than I was to my husband."

11 "Pepsi. Our little girl. Gone for a walk." "Scamp. Off you go home now. Love Mum and Dad."

12 "Cleo. Oh my child."

${ }^{13}$ Min: man (Doric, dialect of North-East Scotland)

14 "That town bypass is still doing a good job eh?"

15 "Some lads are coming down with saws. Taking the lot away tonight."

${ }^{16}$ Tigh na Mara: House of the Sea (Gaelic)

17 "Don't taste that bad."

18 "Yes, you as well."

${ }^{19}$ In 2008, the Seafield and Strathspey Estate ranked as $15^{\text {th }}$ largest landowner in Scotland, with holdings totaling 84,500 acres. The family property is help under the ownership of Ian Derek Francis Ogilvie-Grant, 13th Earl of Seafield.

http://www.scotsman.com/news/who-owns-scotland-here-s-the-next-five-in-our-top-20-1-1153750
} 
20 https://www.facebook.com/groups/373284116022602/

21 The cemetery's tidal troubles featured on the BBC Scotland television programme 'Landward' in April 2018. The Keeper made an appearance, interviewed on site. 